\title{
Boekbesprekingen
}

\section{Optimising new modes of assessment: in search of qualities and standards}

\begin{abstract}
Segers M, Dochy FJRC, Cascalla E, editors. Optimising new modes of assessment: in search of qualities and standards. Dordrecht: Kluwer Academic Publishers B.V.; 2003. 312 pagina's. ISBN 140201260 8. Prijs: Euro 118.
\end{abstract}

Het staat buiten kijf, dat er veranderingen in het denken over toetsing zijn opgetreden. De redacteuren en de auteurs van dit boek spreken zelfs - terecht - over een paradigmaverschuiving. Een dergelijke verandering in het denken was hard nodig. Toen in de jaren zestig en zeventig het denken over leren en instructie radicaal veranderde en het constructivisme de dominerende theorie werd, zijn ontwikkelingen in toetsing namelijk nog lang blijven steken in het theoretische kader van de testpsychologie. Daar was op zich niets mis mee; die theorie heeft ons veel geleerd over validiteit en betrouwbaarheid als maten voor eerlijkheid en verdedigbaarheid van de toetsing. Op een gegeven moment echter werden deze twee parameters als de enige belangrijke gezien. De ontwikkelingen van moderne - zogenaamde authentieke - toetsvormen hebben daarentegen duidelijk gemaakt dat een breder kader nodig is. Het boek 'Optimising new methods of assessment: in search of qualities and standards' onder redactie van Mien Segers, Filip Dochy en Eduardo Cascalla gaat hierover. In een serie hoofdstukken voert het de lezer op een logische manier door het onderwerp heen.

Het eerste hoofdstuk is een soort algemeen overzicht. Het is helder geschreven en vormt een goede introductie voor de lezer. Het tweede hoofstuk van Birenbaum gaat in op de moderne leertheorieën. Dit hoofdstuk is grondig, maar het vereist toch wel wat voorkennis van de lezer over constructivisme, en ik vond het niet makkelijk leesbaar. In hoofdstuk 3 gaan Gielen et al. in op de invloed van moderne toet- sing op het studiegedrag van studenten. Deze consequentionele validiteit wordt tegenwoordig als een centraal aspect gezien. Er wordt dus niet in eerste instantie gekeken naar de meettechnische eigenschappen van een toets als meting van de uitkomst van onderwijs, maar naar de waarde van toetsing als intrinsiek onderdeel van het onderwijs. Keith Topping vat in het volgende - zeer leesbare - hoofdstuk de belangrijkste kennis op het gebied van zelf- en peerassessment samen. Hoofdstukken 5, 6 en 7 gaan meer in op de waarde van individuele methoden of instrumenten: projectgebaseerde toetsing, OverAll toetsing en portfolio's. De laatste vier hoofdstukken gaan weer over algemenere zaken: studentpercepties over nieuwe toetsaanpakken, het meten van de kwaliteit van het leerproces bij onderwijs via groepswerk, standard-setting bij het toetsen van complexe vaardigheden en toetsing en technologie.

Het boek is de moeite van het lezen meer dan waard, hoewel het niet overal altijd even makkelijk leesbaar is. Soms wordt niet eenvoudig Engels gebruikt. Andere hoofdstukken, zoals dat van Keith Topping daarentegen, blinken uit in helderheid en leesbaarheid.

De overzichtshoofdstukken geven een goed beeld van de huidige stand van zaken, en daarin ligt voor mij ook de kracht van het boek. Ik was zelf wat minder gecharmeerd door de meer research-georiënteerde hoofdstukken. Niet omdat ze niet goed zouden zijn, maar omdat ik ook hier liever een overzicht van de huidige stand van zaken had gehad. Zeker voor diegenen die zich binnen het medisch onderwijs bezighouden met toetsing zal het fijn zijn te weten dat de ontwikkelingen op ons terrein niet veel afwijken van die in de algemene onderwijskunde. Ik heb er in ieder geval heel veel van geleerd.

\section{Lambert Schuwirth}

Afd. Onderwijsontwikkeling en Research

Universiteit Maastricht 


\section{Competentie-assessment, de ontwik- keling en toepassing van self-, peer- en expert assessments in het $\mathrm{HBO}$ : een praktijkvoorbeeld}

\author{
Berkel A van, Hofman $K$, Kinkhorst $G$, Lintelo \\ $L$ te, editors. Competentie-assessment, de \\ ontwikkeling en toepassing van self-, peer- \\ en expert assessments in het $\mathrm{HBO}$ : een prak- \\ tijkvoorbeeld. Utrecht: Lemma; 2003. 164 pa- \\ gina's. ISBN 905931098 5. Prijs Euro 23.50.
}

Dit boek beschrijft de resultaten van een tweejarig project, waarin assessments werden ontwikkeld ten behoeve van de economische HBOopleidingen aan de Faculteit van Economie en Management van de Hogeschool van Utrecht. Het boek bestaat uit twee delen en diverse bijlagen. In deel 1 worden in vier hoofdstukken de algemene kaders van assessments in het hoger onderwijs besproken, onderverdeeld naar definities, een beschrijving van de ontwikkeling en implementatie van assessments, de rol van de assessor en kritische succesfactoren. De nadruk van het boek ligt op het tweede deel. Dit deel beschrijft elf assessment-instrumenten die respectievelijk de twaalf in dit boek gekozen competenties toetsen.

De titel van het boek doet vermoeden dat het op de breedte van het hoger onderwijs ingaat. Op die breedte wordt vooral ingegaan in het eerste deel. In het eerste hoofdstuk worden algemene definities gegeven van de begrippen 'competenties' en 'assessments'. De keuze voor de definitie van het begrip competentie, als zijnde een "onderliggend vermogen om taken in de beroepspraktijk adequaat te kunnen verrichten", geeft richting aan de rest van het boek en de keuze voor instrumenten. Willekeurige voorbeelden van de competenties die worden getoetst zijn mondeling presenteren, luisteren, samenwerken, inlevingsvermogen, creativiteit en lerend vermogen. De keuze van de definitie van een assessment is ruim gekozen. Een assessment wordt gedefinieerd als "toetsing van gedrag en de resultaten aan de hand van een realistische praktijktaak". Het kenmerk 'curriculumonafhankelijkheid' voor een assessment, zoals dat in andere bronnen wordt gebruikt, wordt hier niet gekozen, hetgeen geen verdere consequenties heeft voor de aard van de instrumenten. Wel heeft dit consequenties voor de manier waarop de instrumenten worden ingezet.
De hoofdstukken over implementatie, de rol van assessoren en de kritische succesfactoren beperken zich tot algemeenheden en hebben een beperkte nieuwswaarde. Ook de onderbouwing van keuzes in de totstandkoming van de instrumenten is beperkt. De beschrijving van de instrumenten daarentegen is uiterst helder en volledig. De instrumenten worden met name beschreven als instrumenten die een rol kunnen spelen in het meten van ontwikkeling, wat ze niet ontslaat van nauwkeurigheid en objectiviteit. Toetsing van de beschreven instrumenten op validiteit, betrouwbaarheid en responsiviteit is in de nabije toekomst wenselijk.

Ondanks enkele kanttekeningen springt het boek in op het gat dat in de huidige literatuur bestaat. Veel bronnen schrijven beschouwend over assessments, terwijl dit boek juist het accent legt op werkelijke instrumenten die gebruikt kunnen worden bij een assessment. Het boek geeft herhaaldelijk logische aandachtspunten die voor de ontwikkelaar uiterst handig kunnen zijn. Het geheel heeft geleid tot een praktisch handboek waar ontwikkelaars die aan de slag gaan met het inrichten van competentiegerichte toetsen hun voordeel mee kunnen doen. Dit geldt zeker voor het economische onderwijs en onderwijs waarbij de competenties zijn beschreven op een meer generiek niveau. De auteurs zijn geslaagd in de doelstelling van het boek. Het boek beschrijft opgedane ervaringen tijdens de implementatie van assessments in het onderwijs, waar anderen van kunnen leren.

\author{
Drs. Remco Coppoolse \\ Faculteit Gezondheidszorg, Hogeschool van Utrecht
}

